\title{
Evaluation of the chemical, physical and nutritional composition and sensory acceptability of different sweet potato cultivars
}

\section{Avaliação da composição química, nutricional e da aceitabilidade sensorial de diferentes cultivares de batata-doce}

\author{
Ana Flávia de Oliveira ${ }^{1}$; Jaqueline Machado Soares ${ }^{1}$; Érica Caroline da Silva²; \\ Paulo Sergio Loubet Filho ${ }^{3}$; Camila Jordão Candido ${ }^{4}$; Luane Aparecida do \\ Amaral $^{1}$; Elisvânia Freitas dos Santos ${ }^{5}$; Juliano Tadeu Vilela de Resende ${ }^{6}$; \\ Kélin Schwarz; Daiana Novello ${ }^{6^{*}}$
}

\begin{abstract}
The aim of the study was to evaluate the chemical, physical and nutritional composition and sensory acceptability of different sweet potato cultivars to classify the best genotypes for human consumption. We evaluated ten genotypes extracted from the Germplasm bank of Midwest State University, Brazil. The cultivars were evaluated regarding their sensory acceptability and chemical (reducing sugar; nonreducing sugar; total sugar; $\mathrm{pH}$; total soluble solids; titratable acidity; total soluble solids/titratable acidity ratio; and instrumental colour) and nutritional composition (moisture; ash; protein; lipid; carbohydrate; energy value; total carotenoid; and ascorbic acid). Greater scores $(p<0.05)$ for overall acceptance were obtained for the white pulp genotypes Amorano, Júlia, UGA 45, and UGA 49. There was a statistical difference $(\mathrm{p}<0.05)$ in the chemical and nutritional composition of sweet potatoes, except for the $\mathrm{pH}$ values. Generally, tuber have a light colour (values of $L^{*}$ greater than 50 ) with a yellow shade $\left(b^{*}\right)$ and green subshade (negative $a^{*}$ values). The exception was noticed in the UGA 34 genotype, which presented a higher red shade (positive $a^{*}$ value) and a yellow subshade. The cultivars more indicated for human consumption were the UGA 34 (favorable nutritional profile), UGA 45 (better acceptability and favorable chemical and nutritional composition), and Amorano (better acceptability and favorable chemical composition). On the other hand, the UGA 29 genotype may be characterized as the less appropriated for consumption. That, due to its less acceptance from the consumers and an inferior chemical and nutritional characterization. We conclude that the Brazilian sweet potato cultivars more indicated for human consumption are the UGA 34, UGA 45 and Amorano, considering that present more favorable chemical, nutritional and sensory acceptability characteristics. The UGA 29 genotype may be characterized as less recommended for consumption.
\end{abstract}

Key words: Genotypes. Ipomoea batatas. Tuberous root.

\footnotetext{
1 Nutricionistas, Universidade Estadual do Centro-Oeste, UNICENTRO, Guarapuava, PR, Brasil. E-mail: annaf.olivera@hotmail. com; jaquue.s@gmail.com; luapamaral@hotmail.com

2 Dra ${ }^{\mathrm{a}}$, Pós-Graduação em Saúde e Desenvolvimento na Região Centro-Oeste, Universidade Federal de Mato Grosso do Sul, UFMS, Campo Grande, MS, Brasil. E-mail: ericacarols@yahoo.com.br

3 Nutricionista, Universidade Federal de Mato Grosso do Sul, UFMS, Campo Grande, MS, Brasil. E-mail: paullo.loubet@gmail. com

4 M.e., Pós-Graduação em Saúde e Desenvolvimento na Região Centro-Oeste, Universidade Federal de Mato Grosso do Sul, UFMS, Campo Grande, MS, Brasil. E-mail: cahjordao@gmail.com

5 Prof Dr $^{\mathrm{a}}$, UFMS, Campo Grande, MS, Brasil. E-mail: elisvania@gmail.com

6 Profs. Drs., UNICENTRO, Guarapuava, PR, Brasil. E-mail: jvresende@uol.com.br; nutridai@gmail.com

7 Prof ${ }^{\mathrm{a}}$ Dra $^{\mathrm{a}}$, Universidade Federal do Triângulo Mineiro, UFTM, Uberaba, MG, Brasil. E-mail: kelinschwarz@hotmail.com Author for correspondence
} 


\section{Resumo}

O objetivo deste trabalho foi avaliar a composição química, física e nutricional e a aceitabilidade sensorial de diferentes cultivares de batata-doce, visando classificar os melhores genótipos para o consumo humano. Foram avaliados 10 genótipos extraídos do Banco de Germoplasma da UNICENTRO, Guarapuava, PR. Os cultivares foram avaliados em relação à aceitabilidade sensorial e à composição química (açúcares redutores; açúcares não redutores; açúcares totais; $\mathrm{pH}$; sólidos solúveis totais; acidez titulável; relação sólidos solúveis totais/acidez titulável; cor instrumental) e nutricional (umidade; cinzas; proteína; lipídio; carboidrato; energia; carotenoides totais e; ácido ascórbico). Maiores notas $(\mathrm{p}<0,05)$ para aceitação global foram verificadas para os genótipos de polpa creme Amorano, Júlia, UGA 45 e UGA 49. Houve diferença estatística $(\mathrm{p}<0,05)$ na composição química e nutricional das batatas-doces, com exceção dos valores de $\mathrm{pH}(\mathrm{p}>0,05)$. Em geral, os tubérculos apresentaram cor clara (valores de $L^{*}$ maiores que $50 \%$ ), com tom de amarelo $\left(b^{*}\right)$ e subtom de verde (valores de $a^{*}$ negativos). Exceção foi verificada para o genótipo UGA 34, que apresentou maior tom de vermelho (valor de $a^{*}$ positivo) e subtom de amarelo. As cultivares mais indicadas para o consumo humano foram UGA 34 (perfil nutricional favorável), UGA 45 (melhor aceitabilidade e favorável composição química e nutricional) e Amorano (melhor aceitabilidade e favorável composição química). Contrariamente, o genótipo UGA 29 pode ser caracterizado como o menos propício ao consumo. Isso, porque apresentou menor aceitação pelos consumidores, além de inferior caracterização química e nutricional. Conclui-se que as cultivares de batata-doce brasileiras mais indicadas para consumo humano são a UGA 34, UGA 45 e Amorano, considerando que apresentam características químicas, nutricionais e de aceitabilidade sensorial mais favoráveis. O genótipo UGA 29 pode ser caracterizado como o menos recomendado para o consumo.

Palavras-chave: Genótipos. Ipomoea batatas. Raiz tuberosa.

\section{Introduction}

Originating from Central and South America, sweet potato (Ipomoea batatas) is a root of underground growth and high productivity between the months of April and May. Sweet potato is the sixth more important culture in the world after wheat, rice, corn, potato and cassava (UGA EXTENSION, 2012; TANG et al., 2015). Additionally, it is a basic food in many underdeveloped countries (TRUONG et al., 2011). It is grown in more than 100 countries, from which China is it largest producer (117 million tons/year) (GUO et al., 2014). According to the International Potato Center (IPC, 2016), more than 6.500 cultivars of sweet potato were registered in the world between 1895 and 2000. However, new cultivars are periodically produced, which shows the importance of this food's chemical, nutritional and sensory characterizations. In Brazil, the sweet potato production is present in $24 \%$ of the cities, with an average productivity of 15 tons/hectare
(EMBRAPA, 2015). Its growth occurs mainly in regions with altitudes of up to 2.500 meters, of tropical, subtropical, and temperate climate. In this subject, the states of Rio Grande do Sul, São Paulo, Paraná, Sergipe, Santa Catarina and Minas Gerais, which present favorable climate conditions, are highlighted (IBGE, 2015; IPC, 2016). Sweet potato has several colours, including several shades of white, light pink, dark purple, red and white, brown orange and yellow (TANG et al., 2015).

Sweet potato has a good nutritional profile, underscoring its low lipid level and high contents of fiber, minerals and vitamin C. Besides these nutrients, important substances such as carotenoids, especially the $\beta$-carotene, are also found in sweet potato, with highlight in those with an orange colour (IPC, 2016). Nowadays, several nutritional benefits related to sweet potato consumption are known. One of them is related to the presence of resistant starch because it promotes a slow and 
gradual absorption of glucose, which increases the satiety sensation in the organism. Additionally, purple pulp cultivars may contain expressive levels of anthocyanins and phenolic compounds, which exert an antioxidant activity in the organism and contribute to the pigmentation of the roots (LEBOT et al., 2016). We should also underscore that sweet potato has a low glycemic rate $(<55)$, which favors its consumption among subjects that are carriers of pathologies such as diabetes mellitus or obesity (ALLEN et al., 2012).

In Brazil, sweet potato is mostly consumed baked or cooked and industrialized as candies (TANG et al., 2015). However, during thermal processing, the starch undergoes several structural modifications. Additionally, it might present changes in the reducing sugar, $\mathrm{pH}$ and acidity levels, as well as colour, appearance and smell. One example of these heat-induced changes is the raw sweet potato natural light colour changing into different shades of gray and green. All these factors may directly influence the sensory acceptability of the cultivars by the consumers. Additionally, it was proven that sweet potatoes with white-coloured pulps have a greater sensory acceptability and high technological potential in comparison with the purple-coloured ones (ELLONG et al., 2014). Consequently, understanding the differences between the sweet potato cultivars cooperate to increase their commercialization and strengthen their consumption by the population. The purpose hereof was to evaluate the chemical, physical and nutritional composition and sensory acceptability of different sweet potato cultivars to classify the best genotypes for human consumption.

\section{Materials and Methods}

The experiment was installed in the Cedeteg Campus of the Midwest State University, in Guarapuava, Paraná, Brazil (25²3'42”S, $51^{\circ} 27^{\prime} 2^{\prime \prime} \mathrm{W}, 1.120 \mathrm{~m}$ high). The division was made in randomized blocks with three repetitions and ten treatments. The genotypes came from the sweet potato Germplasm Bank of Midwest State University, kept by the Olericulture Sector of the Agronomy Department. The following cultivars were researched: UGA 29 (peel and pulp white); UGA 34 (peel and pulp purple); UGA 45 (purple peel and white pulp); UGA 49 (peel and pulp white); UGA 79 (peel and pulp white); UGA 80 (purple peel and white pulp); UGA 81 (peel and pulp white); Amorano (purple peel and white pulp); Júlia (peel and pulp white) and Valentina (peel and pulp purple). Each replicate was composed of a three tuberous roots samples, with an average weight of 500 to $700 \mathrm{~g}$.

The experimental soil area was prepared by plowing and harrowing. The planting beds were raised side by side, spaced $80 \mathrm{~cm}$ apart, with the aid of a duck nozzle. The soil chemical analysis did not identify the need for liming. The branches, taken from the parent plants of the different genotypes, were planted in the spring season in 50 cell trays. The intermediate and superior portions of the vegetative structures of the sweet potato plant (three internodes) were used. After 30 days, the seedlings were transplanted to the field, in plots composed of 6 seedlings of each genotype. Plants were arranged in plots with a useful area of $2.0 \mathrm{~m}^{2}$, spaced $30 \mathrm{~cm}$ apart. Irrigation used was sprinkler type, being performed once a day for 30 minutes in the first month after planting or when necessary, since the pluviometric regime in this period was quite intense. Planting fertilization consisted of $40 \mathrm{~kg} \mathrm{ha}^{-1}$ of nitrogen, $80 \mathrm{~kg} \mathrm{ha}^{-1}$ of phosphorus and $90 \mathrm{~kg} \mathrm{ha}^{-1}$ of potassium (SILVA et al., 2008) and replacement fertilization was performed 60 days after planting, with $100 \mathrm{~g} \mathrm{portion}^{-1}$ of fertilizer $20-00-20$ (kg nitrogen-kg phosphorus-kg potassium, respectively, in $100 \mathrm{~kg}$ of fertilizer). Weed control was done by manual weeding until 45 days after transplanting. After this period, plants covered the beds and control was no longer necessary. No phytosanitary 
controls were carried out. Harvest was performed after 157 days of planting in the field, at the end of the summer, and with commercial maturation stage to consumption. After harvesting, sweet potatoes were stored in raffia bags, duly identified and stored at room temperature $\left(22^{\circ} \mathrm{C}\right)$ until analysis.

Sweet potatoes with better visual appearance were used. Those with defects and/or presenting very different size and appearance were excluded. The samples were then washed in running water, followed by sanitization in sodium hypochlorite solution (150 ppm) for 15 minutes. The tips of the tuberous roots were discarded and the medial part cut into cylinders approximately $3 \mathrm{~cm}$ of length. Sweet potatoes $(100 \mathrm{~g})$ were immersed in $1 \mathrm{~L}$ of boiling water $\left(100^{\circ} \mathrm{C}\right)$ and cooked until the material showed no resistance to drilling by stainless steel knife. They were manually peeled, cut $(2 \mathrm{~cm} \times 1 \mathrm{~cm})$ and stored in hermetically sealed plastic containers. The samples were kept under refrigeration until analysis $\left(8^{\circ} \mathrm{C}\right)$.

For conducting the sensory test, sweet potatoes have been cooked as previously described. The sensory evaluation occurred through an overall acceptance test, using a nine point hedonic scale, with extremes ranging from dislike extremely (1) to like extremely (9). In the purchase intent test, a 5-point attitude structured scale was used, varying from 1 (definitely would not buy it) to 5 (definitely would buy it) (MEILGAARD et al., 1999). Sixty untrained individuals (18 to 60 years old), habitual consumers of sweet potatoes, participated in the sensory evaluation. Individuals were recruited among students and staff of Midwestern State University. Each sample (about $15 \mathrm{~g}$ ) was served to consumers in white plates coded with randomly selected 3-digit numbers in monadic form and using balanced design (MACFIE et al., 1989). Sensory evaluations were performed by consumers under fluorescence lighting. After consuming each sample, consumer was instructed to drink water for palate cleansing. Samples were evaluated in triplicate in separate session. The project was approved by the Research Ethics Committee of Midwest State University, ruling $\mathrm{n}^{\circ}$. 608.950/2014.

For chemical, physical and nutritional evaluations, the raw sweet potatoes were ground in a domestic blender (Mondial ${ }^{\circledR}$, Brazil) and stored in aluminum bags at $-20{ }^{\circ} \mathrm{C}$ until analysis. The determinations were performed in triplicate in peeled raw sweet potatoes. The results were expressed in wet weight basis. The following chemical evaluations were performed: Reducing Sugars (RS), Nonreducing Sugars (NRS) and Total Sugars (TS), evaluated by Lane-Eynon reductometric method of Association of Official Analytical Chemists

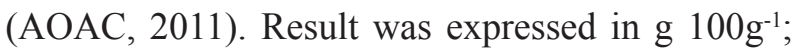
$\mathrm{pH}$, by means of direct reading in digital $\mathrm{pH}$ meter (Analyser $^{\circledR}$, 300M model, Brazil); Total Soluble Solids (TSS), measured in a digital refractometer (Hanna Instruments ${ }^{\circledR}$, Brazil, model HI 96801) and expressed in ${ }^{\circ}$ Brix; Titratable Acidity (TA) assessed according to AOAC (2011) and expressed in citric acid percentage (\%); and Total Soluble Solids/ Titratable Acidity (TSS/TA) ratio. The colour analysis was performed in the pulp of raw sweet potatoes and in quintuplicate. The $L^{*}, a^{*}$, and $b^{*}$ Commission Internationale de L'éclairage (CIE) system was used, with a reading in a colorimeter (Konica Monilta ${ }^{\circledR}$, Chroma Meter CR 4400 model, Japan) with a previously calibrated D65 illuminant and a $10^{\circ}$ angle. The analyzed parameters were $L^{*}$ (lightness), $a^{*}$ (red-green component) and $b^{*}$ (yellow-blue component), besides Chroma and Hue. The proximate composition was evaluated: ash ( $\mathrm{g}$ $\left.100 \mathrm{~g}^{-1}\right)$, protein $\left({\left.\mathrm{g} 100 \mathrm{~g}^{-1}\right)}\right.$ (AOAC, 2011), lipid (g $\left.100 \mathrm{~g}^{-1}\right)$ (BLIGH; DYER, 1959) and carbohydrate $\left(\mathrm{g} 100 \mathrm{~g}^{-1}\right)$, by difference: \% Carbohydrate $=100$ - $(\%$ moisture $+\%$ protein $+\%$ lipid $+\%$ ash + $\%$ fiber). Total energy value (kcal $100 \mathrm{~g}^{-1}$ ) was calculated using values recommended by Merril and Watt (1973) for lipid (8.37 $\left.\mathrm{kcal} \mathrm{g}^{-1}\right)$, protein (3.11 kcal g-1) and carbohydrate (3.99 kcal g $\mathrm{g}^{-1}$ ). The total carotenoid determination $\left(\mu \mathrm{g} \mathrm{g}^{-1}\right)$ was 
performed by a spectrophotometric analysis (450 nm) (RODRIGUEZ-AMAYA, 2001). The ascorbic acid (vitamin $\mathrm{C}$ ) content was evaluated by titration with 2.6 dichlorophenolindofenol (AOAC, 2011) and results expressed in $\mathrm{mg} 100 \mathrm{~g}^{-1}$.

The results were analyzed using analysis of variance (ANOVA). The means were compared by Scott-Knott Test at 5\% significance level $(\mathrm{p}<0.05)$. The Statistical Analysis System software (North Carolina, USA) was used to perform the statistical calculations.

\section{Results and Discussion}

In general, differences in the overall acceptance and the purchase intent among the sweet potato cultivars were observed (Table 1). Greater scores ( $p$ $<0.05)$ for these evaluations were noticed for the white pulp genotypes Amorano, Júlia, UGA 45 and UGA 49. There was no statistic difference $(p>0.05)$ in the overall acceptance between all other sweet potatoes. However, lower purchase intent was noticed for the UGA 29 cultivar, as no significant difference was noticed for all other samples. Leksrisompong et al. (2012) noticed similar effects, since the white pulp sweet potato varieties (Japanese, Puerto Rican, O-Henry, DM02-180) were more accepted than the purple pulp ones (NC414, NC415, Okinawa, Purple 04-069). The authors also reported that the purplecoloured pulp sweet potatoes visibly presented more fibers and were firmer in comparison with the white-coloured pulp ones, which also was noticed herein. Additionally, the polyphenols present in the fibers may suffer oxidation, darkening the food, which may reduce its acceptability (OIRSCHOT et al., 2003).

Table 1. Sensory scores* of Brazilian sweet potato cultivars.

\begin{tabular}{lcc}
\hline Cultivar & Overall acceptance & Purchase intent \\
\hline Amorano & $6.7^{\mathrm{a}}$ & $3.5^{\mathrm{a}}$ \\
Júlia & $6.8^{\mathrm{a}}$ & $3.7^{\mathrm{a}}$ \\
Valentina & $6.3^{\mathrm{b}}$ & $3.3^{\mathrm{b}}$ \\
UGA 29 & $5.6^{\mathrm{b}}$ & $2.9^{\mathrm{c}}$ \\
UGA 34 & $6.4^{\mathrm{b}}$ & $3.4^{\mathrm{b}}$ \\
UGA 45 & $7.1^{\mathrm{a}}$ & $4.0^{\mathrm{a}}$ \\
UGA 49 & $6.8^{\mathrm{a}}$ & $3.7^{\mathrm{a}}$ \\
UGA 79 & $6.1^{\mathrm{b}}$ & $3.3^{\mathrm{b}}$ \\
UGA 80 & $6.2^{\mathrm{b}}$ & $3.4^{\mathrm{b}}$ \\
UGA 81 & $6.2^{\mathrm{b}}$ & $3.4^{\mathrm{b}}$ \\
CV $(\%)^{*}$ & 1.6 & 2.0 \\
\hline
\end{tabular}

* Mean of 60 values; Distinct letters in column are significantly different by the Scott-Knott Test $(p<0.05)$; CV (\%): Coefficient of Variation. 
A significant difference was noticed in the chemical composition of the sweet potatoes (Table 2). There was variability in the levels of RS (1.38 to

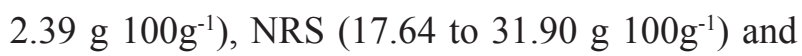

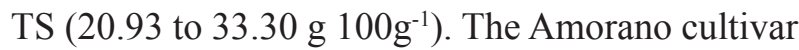
presented the greatest level of RS, as Valentina, UGA 34 and UGA 45 the lowest ones. Both for the NRS and TS, the UGA 45 and UGA 29 genotypes were highlighted, because they presented the greatest and lowest levels, respectively. The elevated presence of $\mathrm{RS}$ in sweet potatoes may promote colour changes through a non-enzymatic darkening (Maillard reaction), when submitted to thermal processing. Consequently, there might happen an acceptability reduction of the consumer. On the other hand, we know that the RS present a greater sugaring ability in comparison with the NRS ones, which may improve the food's flavour (BOBBIO; BOBBIO, 2001). This effect was confirmed herein because the Amorano genotype, with greater RS level, also presented an elevated acceptance.

There was no $\mathrm{pH}$ variation $(\mathrm{p}>0.05)$ between the genotypes (5.61 to 6.69), corroborating with evaluations performed in sweet potatoes originating from Spain (SUÁREZ et al., 2016). Similar pH values are common in genotypes produced in the same environment and/or growth cycle (SUÁREZ et al., 2016), which happened herein. According to Feltran et al. (2004), sweet potato pulp pH values above 6.0 indicate that their roots are in a good maturation and conservation condition. On the other hand, a $\mathrm{pH}$ between 4.7 and 5.5 may favor the action of deteriorating enzymes in the product. 


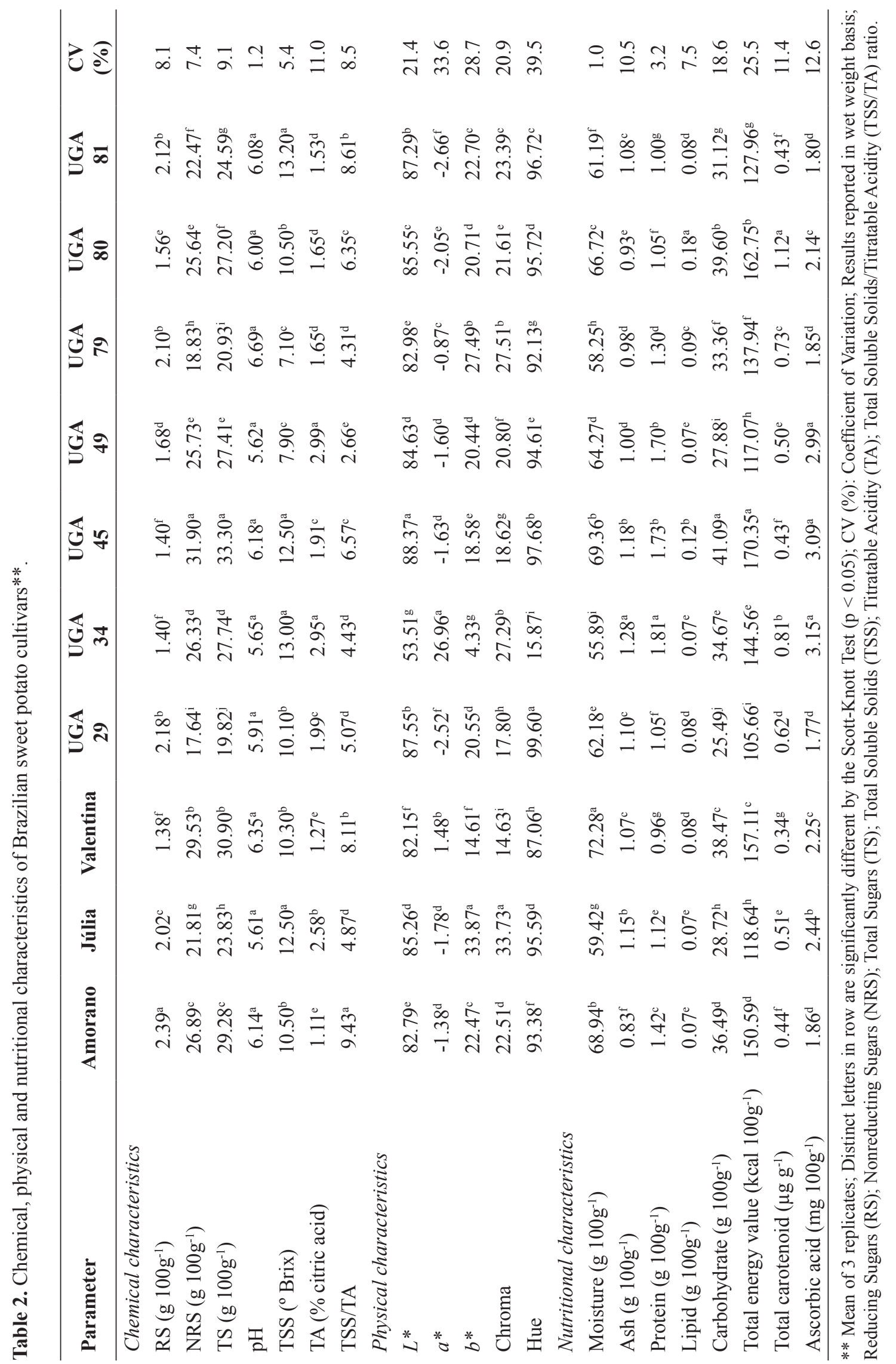


A greater TSS level ( ${ }^{\circ}$ Brix) was found in the cultivars Júlia, UGA 34, UGA 45 and UGA 81, however UGA 49 and UGA 79 presented lower concentrations. Elevated TSS levels are signs of greater sucrose contents in the food and it can increase its acceptability by the consumers. This fact was confirmed herein for the genotypes Júlia and UGA 45. The TA level (\% citric acid) quantifies the concentration of organic acids present in the foods, which vary between 1.11 to 2.99 in the evaluated genotypes, corroborating with the literature (FELTRAN et al., 2004). The UGA 34 and UGA 49 cultivars presented greater acidity, as the Amorano and Valentina cultivars were the less acid. Generally, the TA concentration depends on factors such as the amount of proteins and salts present in the product, the buffer capacity of these components and, especially, the TSS level (MCCARTHY et al., 1991). Pineli et al. (2005) explain that, during the food's storage, the starch conversion may increase the roots metabolic activity. Consequently, there might occur the degradation of other components, including the organic acids. Therefore, lower TA levels may improve the flavour and smell, which may explain the greater acceptability of the Amorano genotype (Table 1). Similarly, more elevated values of the TSS/TA ratio indicate a more pleasant flavour, since they indicate a balance between the levels of the food's sugars and acids (FERNANDES et al., 2010). This effect was confirmed for the Amorano genotype, which presented the greatest TSS/ TA ratio (9.43), but not for the UGA 49 cultivar, which presented the lowest result (2.66) but high acceptability. This shows that there are other factors that interfere directly in the acceptance of a food by the consumer.

The $L^{*}, a^{*}, b^{*}$, Chroma and Hue values varied between the sweet potato cultivars, mainly for Júlia, UGA 29, and UGA 34 cultivars. The Júlia cultivar presented higher $b^{*}$ (yellow) and Chroma values, as the UGA 29 had a lower $a^{*}$ (red) and higher Hue values, which in this case was closer to yellow. The
UGA 34 genotype was highlighted by its lower values of $L^{*}$ (lightness), $b^{*}$ and Hue, and higher values of $a^{*}$. These results are explained by its intense purplecoloured pulp. Generally, sweet potatoes may be considered as light-coloured (all $L^{*}$ values were higher than 50), with a yellow shade $\left(b^{*}\right)$ and green subshade (negative $a^{*}$ values). An exception was verified for the UGA 34 genotype, which presented a higher red shade (positive $a^{*}$ value) and yellow subshade. Tang et al. (2015) noticed similar effects evaluating different varieties (Gui 04-53, Gui 0975, Guishu \#2, Guineng 05-6 and Guijungshu 09-7) of raw sweet potatoes originating from China.

There was a variation $(p<0.05)$ in the nutritional composition between the sweet potato cultivars (Table 2). The moisture level varied from $55.89 \%$ (UGA 34) to $72.28 \%$ (Valentina). Similar results $(59.35 \%$ to $63.45 \%)$ were reported by Dincer et al. (2011), which evaluated sweet potato varieties (Beniazuma, Koganesengan and Kotobuki) originating from Turkey. The moisture differences between the cultivars are explained by the levels of starch, fiber, bound water, storage and type of cultivar (ALVES et al., 2011). Greater ash and protein concentrations were found in the UGA 34 cultivar, which has a purple pulp. On the other hand, the Amorano genotype presented the lower ash content, as the Valentina and UGA 81 cultivars presented the lower protein levels. According to Sanoussi et al. (2016), the ash level

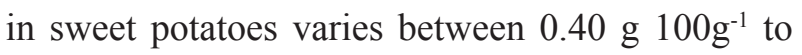

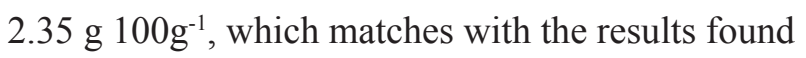

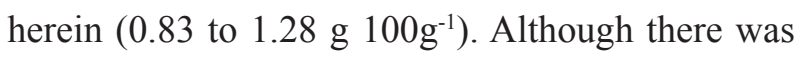
a small variation in the lipid quantification $(0.07$

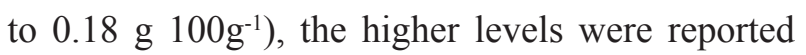
for the UGA 80 cultivar and the lowest ones for the Amorano, Júlia, UGA 34 and UGA 49 cultivars. The composition of carbohydrate and energy value was higher in the UGA 45 genotype and inferior for the UGA 29 genotype. Generally, the nutritional composition results are close to the ones seen in the literature (DINCER et al., 2011). 
The carotenoids and the ascorbic acid are important nutrients for the human health because of their vitamin action and more recently also by antioxidant function in the organism. In this context, the UGA 80 cultivar, which presented the greatest levels of total carotenoid, and the UGA 34, UGA 45 and UGA 49 cultivars, which presented the greatest contents of ascorbic acid, may be considered more positive options for human consumption. The Valentina genotype was the one with the lower content of total carotenoid, as the Amorano, UGA 29, UGA 79 and UGA 81 genotypes were the ones with a less adequate nutritional profile regarding the vitamin C.

Generally, the differences seen in the acceptability and in the chemical and nutritional composition between the sweet potato cultivars studied herein are due especially to their intrinsic characteristics (genetics). Other interfering factors, such as growth conditions (climate, soil, and use of fertilizers), conditions pre- and post-harvest and type of storage, present low influence because all genotypes received the same methodological treatment (TRUONG et al., 2011). Therefore, considering all evaluations performed, the cultivars more indicated for human consumption were the UGA 34 (favorable nutritional profile), UGA 45 (better acceptability and favorable chemical and nutritional composition) and Amorano (better acceptability and favorable chemical composition). On the other hand, the UGA 29 genotype may be characterized as the less proper for consumption because it presented less acceptance by the consumers, besides of a chemical and nutritional inferior characterization in comparison with all others. Besides these observations, we underscore that purple-coloured pulp sweet potatoes present a greater antioxidant capacity due to the presence of bioactive compounds, such as anthocyanins (SUÁREZ et al., 2016). Effect that might be present in the UGA 34 and Valentina cultivars, since they present purple-coloured pulps. Another nutritional benefit of the sweet potatoes is related to their low carbohydrate composition, since they might be classified as complex and with low glycemic index $(<55)$. In this context, sweet potatoes become a potential food for diabetic patients, since they can help to stabilize their blood glucose level, which reduces their resistance to insulin (ALLEN et al., 2012; SUÁREZ et al., 2016).

\section{Conclusion}

We conclude that the Brazilian sweet potato cultivars more indicated for human consumption is the UGA 34, UGA 45 and Amorano, considering that present more favorable chemical, nutritional and sensory acceptability characteristics. The UGA 29 genotype may be characterized as less recommended for consumption.

\section{Acknowledgements}

The authors thank Fundação Araucária/Paraná and Coordenação de Aperfeiçoamento de Pessoal de Nível Superior (CAPES)/Brazil for financial support.

\section{References}

ALlEN, J. C.; CORBITT, A. D.; MALONEY, K. P.; BUTT, M. S.; TRUONG, V. Glycemic index of sweet potato as affected by cooking methods. The Open Nutrition Journal, Lexington, v. 6, n. 1, p. 1-11, 2012. DOI: $10.2174 / 1874288201206010001$

ALVES, N. E.; PAULA, L. R.; CUNHA,A. C.;AMARAL, C. A. A.; FREITAS, M. T. Efeito dos diferentes métodos de cocção sobre os teores de nutrientes em brócolis (Brassica oleracea L. var. italica). Revista do Instituto Adolfo Lutz, São Paulo, v. 70, n. 4, p. 507-513, 2011.

ASSOCIATION OF OFFICIAL ANALYTICAL CHEMISTRY - AOAC. Official methods of analysis of AOAC international. $18^{\text {th }}$ ed. Gaithersburg: AOAC, 2011.

BLIGH, E. G.; DYER, W. J. A rapid method of total lipid extraction and purification. Canadian Journal of Biochemistry and Physiology, Ottawa, v. 37, n. 8, p. 911917, 1959. DOI: 10.1139/o59-099 
BOBBIO, F. O.; BOBBIO, P. A. Introdução à química de alimentos. São Paulo: Varela, 2001. 228 p.

DINCER, C.; KARAOGLAN, M.; ERDEN, F.; TETIK, N.; TOPUZ, A.; OZDEMIR, F. Effects of baking and boiling on the nutritional and antioxidant properties of sweet potato [Ipomoea batatas (L.) Lam.] cultivares. Plant Foods for Human Nutrition, Dordrecht, v. 66, n. 4, p. 341-347, 2011. DOI: 10.1007/s11130-011-0262-0

ELLONG, E. N.; BILLARD, C.;ADENET, S. Comparison of physicochemical, organoleptic and nutritional abilities of eight sweet potato (Ipomoea batatas) varieties. Food and Nutrition Sciences, Wuhan, v. 5, n. 2, p. 196-211, 2014. DOI: $10.4236 /$ fns.2014.52025

EMPRESA BRASILEIRA DE PESQUISA AGROPECUÁRIA - EMBRAPA. Ministério da Agricultura, Pecuária e Abastecimento. A importância socioeconômica da batata-doce para a agricultura brasileira. Brasília: Embrapa, 2015. Available at: $<$ https:// www.embrapa.br/busca-de-noticias/-/noticia/7893745/aimportancia-socioeconomica-da-batata-doce-para-aagricultura-brasileira>. Accessed at: 1 may 2018.

FELTRAN, J. C.; LEMOS, L. B.; VIEITES, R. L. Technological quality and utilization of potato tubers. Scientia Agricola, São Paulo, v. 61, n. 6, p. 598-603, 2004. DOI: $10.1590 / \mathrm{S} 0103-90162004000600006$

FERNANDES, A. M. Crescimento, produtividade, acúmulo e exportação de nutrientes em cultivares de batata (Solanum tuberosum L.). 2010. Dissertação (Mestrado em Agronomia) - Universidade Estadual Paulista, Faculdade de Ciências Agronômicas, Botucatu.

GUO, J. J.; LIU, L. Z.; LIAN, X. J.; LI, L.; WU, H. The properties of diferent cultivars of Jinhai sweet potato starches in China. International Journal of Biological Macromolecules, Guildford, v. 67, n. 1, p. 1-6, 2014. DOI: 10.1016/j.ijbiomac.2014.03.002

INSTITUTO BRASILEIRO DE GEOGRAFIA E ESTATÍSTICA - IBGE. Produção agrícola municipal. Brasília: IBGE, 2015. Available at: <http://cidades.ibge. gov.br/comparamun/compara.php?coduf $=$ undefined\&co $\mathrm{dv}=\mathrm{V} 31$ \&idtema $=149 \&$ lista $=$ capitais $>$. Accessed at: 15 jun. 2018.

INTERNATIONAL POTATO CENTER - IPC. Sweetpotato facts and figures. Lima: IPC, 2016. Available at: <http://cipotato.org/sweetpotato/facts-2>. Accessed at: 2 jul. 2018.

LEBOT, V.; MICHALET, S.; LEGENDRE, L. Identification and quantification of phenolic compounds responsible for the antioxidant activity of sweet potatoes with different flesh colours using high performance thin layer Chromatography (HPTLC). Journal of Food
Composition and Analysis, San Diego, v. 49, n. 1, p. 94101, 2016. DOI: 10.1016/j.jfca.2016.04.009

LEKSRISOMPONG, P. P.; WHITSON, M. E.; TRUONG, V. D.; DRAKE, M. A. Sensory attributes and consumer acceptance of sweet potato cultivars with varying flesh colors. Journal of Sensory Studies, Raleigh, v. 27, n. 1, p. 59-69, 2012. DOI: 10.1016/j.jfca.2016.04.009

MACFIE, H. J.; BRATCHELL, N.; GREENHOF, K.; VALLIS, L. V. Designs to balance the effect of order presentation and first-order carry-over effects in hall tests. Journal of Sensory Studies, Raleigh, v. 4, n. 2, p. 129148, 1989. DOI: 10.1111/j.1745-459X.1989.tb00463.x

MCCARTHY, M. J.; PEREZ, E.; OZILGEN, M. Model for transient moisture profiles of a drying apple slab using the data obtained with magnetic resonance imaging. Biotechnology Progress, New York, v. 7, n. 6, p. 540543, 1991. DOI: 10.1021/bp00012a009

MEILGAARD, M.; CIVILle, G. V.; CARR, B. T. Sensory evaluation techniques. $3^{\text {th }}$ ed. Florida: CRC Press, 1999. $387 \mathrm{p}$.

MERRIL, A. L.; WATT, B. K. Energy values of foods: basis and derivation. Washington: United States Department of Agriculture Handbook, 1973. 105 p.

OIRSCHOT, Q. E. A. V.; REES, D.; AKED, J. Sensory characteristics of five sweet potato cultivars and their changes during storage under tropical conditions. Food Quality and Preference, Barking, v. 14, n. 8, p. 673-680, 2003. DOI: 10.1016/S0950-3293(02)00209-4

PINELI, L. L. O.; MORETTI, C. L.; ALMEIDA, C. A. O.; NASCIMENTO, A. B. G. Caracterização química e física de batatas Ágata minimamente processadas, embaladas sob diferentes atmosferas modificadas ativas. Pesquisa Agropecuária Brasileira, Brasília, v. 40, n. 10, p. 1035-1041, 2005.

RODRIGUEZ-AMAYA, D. A guide to carotenoid analysis in foods. Washington: Internacional Life Science Institute Press, 2001. $71 \mathrm{p}$.

SANOUSSI, A. F.; DANSI, A.; AHISSOU, H.; ADEBOWALE, A.; SANNI, L. O.; OROBIYI, A.; DANSI, M.; AZOKPOTA, P.; SANNI, A. Possibilities of sweet potato [Ipomoea batatas (L.) Lam] value chain upgrading as revealed by physico-chemical composition of ten elites landraces of Benin. African Journal of Biotechnology, Nairob, v. 15, n. 13, p. 481-489, 2016. DOI: $10.5897 / \mathrm{AJB} 2015.15107$

SILVA, J. B. C.; LOPES, C. A.; MAGALHÃES, J. S. Embrapa hortaliças. Sistemas de produção: batatadoce (Ipomoea batatas). Brasília: Embrapa, 2008. 18 p. Available at: <http://sistemasdeproducao.cnptia. embrapa.br>. Accessed at: 17 jul. 2018. 
SUÁREZ, M. H.; HERNÁNDEZ, A. I. M.; GALDÓN, B. R.; RODRÍGUEZ, L.H.; CABRERA, C. E. M.; MESA, D. R.; HERNÁNDEZ, M. Application of multidimensional scaling technique to differentiate sweet potato (Ipomoea batatas (L.) Lam) cultivars according to their chemical composition. Journal of Food Composition and Analysis, San Diego, v. 46, n. 1, p. 43-49, 2016. DOI: 10.1016/j. jfca.2015.10.008

TANG, Y.; CAI, W.; XU, B. Profiles of phenolics, carotenoids and antioxidative capacities of thermal processed white, yellow, orange and purple sweet potatoes grown in Guilin, China. Food Science and
Human Wellness, Pequim, v. 4, n. 3, p. 123-132, 2015. DOI: $10.1016 /$ j.fshw.2015.07.003

TRUONG, V. D.; AVULA, R. Y.; PECOTA, K.; YENCHO, C. G. Sweet potatoes. In: SINHA, N. K. Handbook of vegetables and vegetable processing. New Jersey: Wiley-Blackwell, 2011. p. 717-737.

UNIVERSITY OF GEORGIA - UGA EXTENSION. Home garden sweet potatoes. Athens: UGA, 2012. Available at: <http://extension.uga.edu/publications/ detail.cfm?number=C 1014>. Accessed at: 23 jul. 2018. 
